DOI: $10.33766 / 2524-0323.93 .297-305$

УДК 343.102:343.9.02(045)

Ostavciuc D., Candidate of Law, Associate Professor at the "Criminal procedure, forensics and information security» Department Rector Academy «Stefan cel Mare» of MIA (Chisinău, Republica Moldova)

e-mail: oastavciuc@mail.ru

ORCID iD: https:/ / orcid.org/0000-0001-5317-3296

Rusnac C., Candidate of Law, Associate Professor at the "Criminal procedure, forensics and information security» Department Academy «Stefan cel Mare» of MIA (city Chisinău, Republica Moldova, MD-2009)

e-mail: navrucnd1@gmail.com

ORCID iD: https:/ / orcid.org/orcid.org/0000-0002-8122-7711

\title{
FEATURES OF PLANNING OF THE INVESTIGATION OF CRIMES COMMITTED BY ORGANIZED CRIMINAL GROUPS
}

Organized crime is a crucial issue because it poses a major threat to the rule of law and has very serious consequences for victims, the economy and social development. In this study, the author, based on a critical examination of the literature, outlines the criteria that would underlie a good planning criminal investigation in case of crimes committed by organized criminal groups.

Keywords: crime, plan, version, victim, circumstance, organized criminal group, criminal proceeding.

Introduction. It is well known that the purpose of a criminal proceeding is to protect individuals, society and the state from crime and to protect individuals and society from illegal acts of officials in the course of investigating crimes either alleged or committed so that any person who has committed a crime is punished to the extent of his/her guilt and no innocent person is subject to criminal liability and convicted.

In the course of proceedings, criminal investigative bodies and the courts shall act in such a manner that no one is unjustifiably suspected, accused or convicted and no one is arbitrarily or unnecessarily subjected to coercive procedural measures [2, art.1].

At the same time, the criminal investigative body must take all measures provided for in the law to make a comprehensive, complete and objective investigation of the circumstances of the case, to identify the circumstances that prove the guilt of the suspect/accused/defendant or that discharge that guilt and to identify any circumstances that mitigate or aggravate their liability [2, art. 254].

Thus, to achieve the purpose of the criminal investigation and to ensure the active role of the criminal investigative body, his/her activity must be well organized and planned.

The purpose of the article is to highlight the tactical aspect of planning the criminal investigation activity in cases of crimes committed by organized criminal groups.

Methods and materials applied. In order to achieve the stated goal, taking into account the specificity and the complex character of the investigated topic, the logical, syste-

(C) Ostavciuc D.,

Rusnac C., 2021 
matic and comparison methods were used as research methods. The research undertaken is based on the study of doctrine, national law and judicial practice.

Presenting main material. The terms of organization and planning of procedural activity, particularly the criminal investigation is interpreted differently. Some authors $[1,6]$ consider these notions as equivalent, while others [3] consider that organization of criminal investigation goes beyond planning the activity.

These issues are not addressed in the present guide as we are interested in the style and manner of organization of the criminal investigation in case of crimes committed by organized criminal groups. M. J. Palmiotto [5, p. 24-30] mentions that criminal investigation management enables conducting criminal investigation activities from an early stage.

Organization of criminal investigation has a significant role both in terms of deciding on using the necessary means and resources, and implementing criminal investigation.

E. Stancu [6, p. 398] cites E. Stelzer and A. Ciopraga mentioning that planning is the link between the aim and tasks of criminal investigation on the one hand, and their implementation through concrete actions on the other hand. It is materialized in investigation objectives, versions and problems to be solved, methods and means available. In order to establish the guilt of a person in a particular criminal case, the investigation objectives shall be determined.

Planning the criminal investigation in all cases shall be carried out with respect for the principle of individuality. This principle is to develop a well thought plan on criminal investigation reflecting procedural and special investigation that need to be performed in order to identify active members of the criminal group, detect means used in committing the crime, identify the crime target, identify and hear crime victims, detect stolen items and the methods of concealing the crime, discover methods of legalization of income acquired illegally and other relevant issues.

The individual nature of planning results from objective and subjective elements that assign specific characteristics to each act of the crime (murder, embezzlement, scams, etc.) committed by organized criminal groups. An individual plan for each cause has to be developed, as certain circumstances should be established for crimes of murder, embezzlement, extortion, etc., in which the criminal group specializes.

Respect for the principle of individuality in planning the criminal investigation has a great practical utility as it impedes development of patterns related to plans that are apparently similar [1, p. 211].

While investigating crimes, especially those committed by criminal groups, the criminal investigation authority given collects and compares evidence at a certain stage of investigation, until finding the truth. Therefore, after each special or criminal investigation measure crime circumstances may undergo several changes, respectively, the direction of investigations may be derived from the originally created picture.

Due to these facts and circumstances, the criminal investigation plan should be adjusted as necessary. It results from the dynamic nature of the criminal investigation plan, which, especially in investigation of offenses committed by organized criminal groups, is characterized by the flexibility to undergo changes at any stage. Crimes committed by criminal groups are usually complex; and the result of investigations can be established from the moment of registration of the criminal act. 
Planning criminal investigation of crimes committed by organized criminal groups include: finding planning tasks at each stage of the investigation; developing the necessary versions at a certain stage of research based on the information available at that stage; identifying problems that need to be resolved according to the version submitted; determining the criminal and special investigative measures to be conducted in order to achieve the desired goal; verifying versions based on the results of special and criminal investigation; assessing these results.

The criminal investigation plan must include: criminal investigation actions and special investigation measures required; versions that will be developed based on factual data available at that stage; circumstances that need to be proven; persons responsible for each action criminal or special investigation measures; execution time, taking into account the behavior of the parties in the process, complexity of the case and other circumstances; progress on execution of these measures and results $[9,10]$.

E. Stancu [6, p. 400-401] considers that the content of the plan results from the issues should be clarified at a particular stage. Finding the truth requires an investigation where certain data and circumstances are discovered, verified, clarified in order to determine the elements of crime identify the criminal and prove guilt. To determine these elements, the prosecution must answer a series of questions, conventionally called «formula of 7 questions» or the «formula of 4 questions» that are applied in most of the cases.

In case of offenses committed by criminal groups, the criminal investigation authority must answer the following questions: whether the act constitutes a crime, what kind of offense was committed, what results produced etc.; if the act committed is an offence, what are the crime circumstances; if it was committed by a criminal group, who are the members of this group and what is the role of each member of the group; what is the reason and purpose of criminal group members.

Criminal investigation authorities perceive the all the changes resulting from the crime not only in terms of search discovery and collection of evidence, but also by conducting a detailed intellectual assessment, a logic interpretation, processing and analysis of available information.

In various stages of investigation of offenses, secondary issues without legal relevance may be explained and give rise to various assumptions [1, p. 214].

Camil Suciu [7, p. 499] mentions that these suppositions and assumptions developed by the criminal investigation authority that designed to explain the possible offense as a whole or certain aspects of it, have assumed the name - versions.

Those assumptions may give an explanation, although likely, of the offense committed by organized crime groups, based on the information available to the prosecuting authority in a certain stage of investigation. As a result it may turn to evidence that may prove the truth or prove the non-existence of the criminal act.

Versions of criminal investigation and special investigations have a significant importance in the course of investigation of crimes committed by organized criminal groups as they streamline the planning process and the activity of relevant authorities.

Information that could form the criminal investigation version may be obtained at any investigation stage.

Thus, information obtained during investigation of crime scene may be relevant for developing criminal investigation versions specifying the procedural actions and special 
investigation measures to be conducted. It ensures the correct direction of the initial investigation stage.

Certainly, the amount of data obtained during or after a crime scene investigation is not always sufficient to assess whether the offense was committed by a criminal group. Initial information obtained from crime scene investigation, hearing of the victim or other data obtained at the initial stage of investigation cannot be assessed, respectively, the criminal investigation authority cannot develop a clear vision whether the offense was committed by an organized criminal group or a criminal association.

Initial data, especially those obtained from crime scene investigation helps to provide versions, which need to be further verified. It is very important to take into account the information and material evidence discovered and collected from the spot. At least they will help the criminal investigation authority to establish whether the offense was committed by two or more persons. It is this particular finding that will help the criminal investigation authority to submit the version on an offense committed by an organized criminal group.

Therefore, it is important that person performing this procedural action to thoroughly examine the scene, objects and traces detected. If there are several footprints, cigarette butts, etc. this means that the offense was committed by a group of people, which is an incentive for to submit the version of the offense committed by an organized criminal group.

Certain authors [8, p. 911]. consider that information gathered during crime scene investigation refers to biological features of offenders and is represented by: anthropological signs (race, gender, age); physical characteristics of offenders (marks, weight, height etc.); functional and anatomical characteristics; biochemical characteristics (smell, the composition of blood, semen, sweat, etc.); pathological anomalies.

Apart from the aforementioned features, crime scene information may point at skills and knowledge of offenders due to which the criminal investigation body may submit versions on the personality and actions of criminals.

Generally speaking, the investigation consists in logical conclusions arising from versions. The version on the existence of a criminal group developed based on crime scene information, the following conclusions on the following data may be drawn up: number of criminals, criminals who directly participated in committing the crime, actions to conceal the crime, use of means and instruments to commit the crime (it will allow to further individualize the punishment for each criminal group member). Any investigation shall be carried out resulting from versions [8, p. 912].

To be noted that in case of developing and submitting criminal investigation versions based on crime scene information, these rely only on material and biological evidence collected. Although these versions are general, they can point at a crime committed by a group of people which will further enable detecting whether the crimes was committed by an organized group or a group of persons.

Another situation refers to the case when the criminal investigation body holds not only crime scene information but also statements of victims and witnesses. These statements may provide more data on the number of persons involved in the crime, their role and functions, means and methods used to commit the crime, means of transport used, communication means and other relevant information.

Having this data available, the criminal investigation body may determine the organization of a group of persons from the initial stage. If the statements of parties show that the 
group of persons who committed the crime acted in an organized manner we can conclude that we deal with an organized criminal group and the criminal investigation is able to properly plan the procedural and special investigation measures [11,12].

Another important element in investigation of crimes committed by organized criminal groups is conducting the investigation by a group of criminal and special investigation officers. A single officer performing criminal investigation will certainly exceed the reasonable deadline. This is beneficial for criminal group members who will try to hide stolen items and destroy evidence. To this end, investigation of a crime by a group of officer will increase the quality and effectiveness of investigations.

According to art. 256 of the Criminal Procedure Code, in case of serious or particularly serious cases, the head of criminal investigation body, after informing the prosecutor, orders criminal investigation to be conducted by several officers. The prosecutor may order carrying out criminal investigation by several officers representing different criminal investigation bodies. The order will contain the name of the officer leading the criminal investigation actions. The suspected, accused, injured party, responsible party will be informed on the order and on their right to reject any of the officers.

According to par. (4) of art. 4 of the Law No. 333 as of 10.11 .2006 on the status of criminal investigation officers, employees of subdivisions of the Ministry of Internal Affairs, Customs Service and National Anticorruption Centre are entitled to carry out criminal investigation based on prosecutor's order upon proposal of criminal investigation officer.

The legal aspects provide the possibility to create criminal investigation groups which are the most effective method to organized criminal investigation in cases related to organized crime provided that the leading officer holds the necessary professional skills to manage each member, plan criminal investigation measures and assess the evidence.

M. Gheorghita [4, p. 77-78] mentions that division of activity areas within the group shall be performed in accordance with the experience and personal skills of each member. The activities related to suspected, accused persons and witnesses are highly important and are assigned to the most experienced criminal investigation officers, while searches, examination of objects and documents are assigned to less experienced officers.

The author considers that in order to ensure information sharing between all group members, it is required that a person is assigned with the task to keep daily record of information obtained and analyses of all materials, and to share the information with the others. Moreover, all information must be reported to the leader of the criminal investigation group as he is the one to decide what measures can be undertaken based on the information, and what information can be shared and with whom.

In this regard, only the leader of the criminal investigation group is entitled to decide on the investigation actions, assign tasks related to special and criminal investigation, plan the activity, etc. It is recommended that daily debriefing meetings with all criminal investigation officers who are part of the group are conducted. During the debriefing, the results and shortcomings shall be discussed. Moreover, it gives the opportunity to exchange experience on procedures used to achieve positive results. An effective method is planning and conducting criminal investigation actions by young specialist together with more experienced officers or even the leader of the criminal investigation group [4, p. 78].

Conclusions. Analyzing the planning of the criminal investigation activity in the cases of committing crimes by organized criminal groups we formulate the following conclusions: 
1. To achieve the purpose of the criminal investigation and to ensure the active role of the criminal investigative body, his/her activity must be well organized and planned.

2. The whole organization of the criminal investigation, its planning, we understand it in a dynamic, not fixit sense, the plan having to correlate, permanently, with data obtained during the criminal investigation, crossing a path from general to private.

3. Planning criminal investigation of crimes committed by organized criminal groups include: finding planning tasks at each stage of the investigation; developing the necessary versions at a certain stage of research based on the information available at that stage; identifying problems that need to be resolved according to the version submitted; determining the criminal and special investigative measures to be conducted in order to achieve the desired goal; verifying versions based on the results of special and criminal investigation; assessing these results.

4. Versions of criminal investigation and special investigations have a significant importance in the course of investigation of crimes committed by organized criminal groups as they streamline the planning process and the activity of relevant authorities.

5. Investigation of a crime by a group of officer will increase the quality and effectiveness of investigations.

6. It is recommended that daily debriefing meetings with all criminal investigation officers who are part of the group are conducted.

\section{Використані джерела:}

1. Ciopraga A., Iacobuță I. Criminalistică. Editura JUNIMEA. Iaşi, 2001. 216 p.

2. Code of Criminal Procedure of the Republic of Moldova. Nr. 122-XV of March 14, 2003. In: Monitorul Oficial of the Republic of Moldova, 05.11.2013, no. 248-251.

3. Doraş S. Gh. Criminalistica, Vol. II, Elemente de tactic. Tipografia Centrală. Chişinău, 1999. $216 \mathrm{p}$.

4. Gheorghiță M. Tratat de metodică criminalistică. CEP USM. Chişinău, 2015. 194 p.

5. Palmiotto M. J. Criminal investigation. Ed. Nelson-Hall Publishers. Chicago. Illois. SUA, 1994. $313 \mathrm{p}$.

6. Stancu E. Tratat de Criminalistică, Ediția a V-a, revăzută şi adăugită. Universul Juridic. Bucureşti, 2010. 848 p.

7. Suciu C. Criminalistica. Editura Didactică şi Pedagogică. Bucureşti, 1972. 90 p.

8. Криминалистика: Учебникдля вузов / Т. В. Аверьянова, Р. С. Белкин, Ю. Г. Корухов, Е. Р. Россинская ; под ред. Р. С. Белкина. Москва : НОРМА (НОРМА-ИНФРА М), 2001.990 с.

9. Расследование преступлений, совершенных организованными формированиями: научно-практическое пособие / под общ. ред. В. Н. Карагодина. Москва : Проспект, 2015.320 c.

10. Меретуков Г. М. Криминалистическое обеспечение расследования преступлений, совершаемых организованными прес тупными группами (преступными организациями): Учебное пособие. Краснодар : Кубанский государственный аграрный уни верситет, 2010. 295 с.

11. Федченко В. М. Розслідування злочинів слідчою та слідчо-оперативною групою: правові та організаційні засади: дис... канд. юрид наук: 12.00 .09 / В. М. Федченко; Нац. акад. внутрішніх справ. Київ, 2004. 250 с.

12. Яблоков Н. П. Криминалистика: учебник / отв. ред. Н. П. Яблоков. 3-е изд., перераб. и доп. Москва : Юристь, 2005. 781 с. 


\section{References:}

1. Ciopraga, A., Iacobuță, I. (2001) Criminalistică. Editura JUNIMEA. Iaşi. [in Moldavian].

2. Code of Criminal Procedure of the Republic of Moldova. Nr. 122-XV of March 14, 2003. (2003) In: Monitorul Oficial of the Republic of Moldova, 05.11.2013, no. 248-251. [in Moldavian].

3. Doraş, S. Gh. (1999) Criminalistica, Elemente de tactic. Tipografia Centrală. Chişinău Vol. II. [in Moldavian].

4. Gheorghiță, M. (2015) Tratat de metodică criminalistică. CEP USM. Chişinău. [in Moldavian].

5. Palmiotto, M. J. (1994) Criminal investigation. Ed. Nelson-Hall Publishers. Chicago. Illois. SUA. [in English].

6. Stancu, E. (2010) Tratat de Criminalistică, Ediția a V-a, revăzută şi adăugită. Universul Juridic. Bucureşti. [in Moldavian].

7. Suciu, C. (1972) Criminalistica. Editura Didactică şi Pedagogică. Bucureşti [in Moldavian].

8. Kriminalistika: Uchebnik dlya vuzov (2001) / T. V. Averyanova, R. S. Belkin, Yu. G. Koruhov, E. R. Rossinskaya (Eds.) et al.; R. S. Belkin (Ed.). Moskva: NORMA (NORMA-INFRA M). [in Russian].

9. Rassledovanie prestuplenij, sovershenny`x organizovanny`mi formirovaniyami: nauchno-prakticheskoe posobie. (2015) / V. N. Karagodin. Moskva : Prospekt. [in Russian].

10. Meretukov, G. M. (2010) Kriminalisticheskoe obespechenie rassledovaniya prestu plenij, sovershaemy'kh organizovanny`mi prestupny`mi gruppami (prestupny`mi organi zacziyami): Uchebnoe posobie. Krasnodar : Kubanskij gosudarstvenny j agrarny`j universite. [in Russian].

11. Fedchenko, V. M. (2004) Rozsliduvannia zlochyniv slidchoiu ta slidcho-operatyvnoiu hrupoiu: pravovi ta orhanizatsiini zasady. Doctor`s thesis. Nats. akad. vnutrishnikh sprav, Kyiv. [in Ukrainian]

12. Yablokov, N. P. (2005) Kriminalistika: uchebnik / N. P. Yablokov. 3-e izd., pererab. i dop. Moskva : Yurist. [in Russian].

Стаття надіӥшиа до редколегії 18.02.2021

Оставчук Д. І., доктор фрілософії, доцент кафедри кримінального процесу, криміналістики та інформаційної безпеки, ректор Академї̈ «Штефан чел Маре» МВС Республіки Молдова (м. Кишинів, Республіка Молдова)

Русняк К. П., доктор філософії, дочент, начальник кафедри кримінального процесу, криміналістики та інформаційної безпеки Академї̈ «Штефан чел Маре» МВС Республіки Молдова (м. Кишинів, Республіка Молдова)

\section{ОСОБЛИВОСТІ ПЛАНУВАННЯ РОЗСЛІДУВАННЯ ЗЛОЧИНІВ, СКОСНИХ ОРГАНІЗОВАНИМИ ЗЛОЧИННИМИ ГРУПАМИ}

Стаття присвячена актуальній проблематищі - плануванню розслідування у справах про злочини, скоєні організованими злочинними групами. Наголошено, що для досягнення мети розслідування та визначення ролі органу кримінального розслідування його діяльність повинна бути належним чином організована та спланована.

Зазначено, що організація розслідування кримінальних справ відіграє важливу роль як при прийнятті рішень про використання необхідних засобів і ресурсів, так і при розслідуванні злочинів. Щодо планування, то розслідування кримінальних справ у всіх випадках здійснюється 3 дотриманням принципу індивідуальності, який полягає в розробці 
добре продуманого плану розслідування кримінальних справ, відображає процесуальне та спеціальне розслідування; засобів, що використовуються в скоєнні злочину; мети злочину; жертв (потерпілих) від злочинів; викрадених предметів та методи приховування злочину; методів легалізації доходів, отриманих незаконним шляхом тощо.

Узагальнено, що планування розслідування злочинів, скоєних організованими злочинними групами, включає: пошук завдань планування на кожному етапі розслідування; розробку необхідних версій на певному етапі дослідження на основі наявної на цьому етапі інформації; визначення проблем, які необхідно розв'язати відповідно до визначеної версії; диференщіацію кримінальних та спеціальних слідчих заходів, що слід провести для досягнення бажаної мети; перевірку версій за результатами спеціального та кримінального розслідування; оцінку результатів.

Зроблено висновок, що вся організація розслідування, іiї планування проводиться динамічно, а не фіксовано; план повинен постійно співвідноситися 3 даними, отриманими в ході розслідування кримінальни х справ, від загального до приватного. За цією категорією справ рекомендовано розслідування злочинів проводити групою офіцерів (усіма працівниками кримінального розшуку), що підвищить якість та ефективність розслідування.

Ключові слова: злочин, план, версія, жертва, обставина, організована злочинна група, кримінальне провадження

Оставчук Д. И., доктор философии, доцент кафедры уголовного процесса, криминалистики и информационной безопасности ректор Академии «Штефан чел Маре» МВД Республики Молдова (г. Кишинёв, Республика Молдова) Русняк К. П., доктор философии, доцент, начальник кафедры уголовного процесса, криминалистики и информационной безопасности Академии «Штефан чел Маре» МВД Республики Молдова (г. Кишинёв, Республика Молдова)

\section{ОСОБЕННОСТИ ПЛАНИРОВАНИЯ РАССЛЕДОВАНИЯ ПРЕСТУПЛЕНИЙ, СОВЕРШЕННЫХ ОРГАНИЗОВАННЫМИ ПРЕСТУПНЫМИ ГРУППАМИ}

Статья посвящена актуальной проблеме - планированию расследования по делам о преступлениях, совершенных организованными преступными группами. Отмечено, что для достижения цели расследования и определения роли органа уголовного расследования его деятельность должна быть должным образом организована и спланирована.

Отмечено, что организация расследования уголовных дел играет важную роль как при принятии решений об использовании необходимых средств и ресурсов, так и при расследовании преступлений. Что же касается планирования, то расследование уголовных дел во всех случаях осуществляется с соблюдением принципа индивидуальности, который заключается в разработке хорошо продуманного плана расследования уголовных дел, отражает процессуальное и специальное расследование, которое необходимо провести для выявления: активных членов преступной группы; средств, используемых при совершении преступления; цели преступления; жертв (потерпевших) от преступлений; похищенных предметов и методов сокрытия преступления; методов легализации доходов, полученных незаконным путем, и тому подобное.

Обобщено что планирование расследования преступлений, совершенных организованными преступными группами, включает: поиск задач планирования на каждом этапе расследования; разработку необходимых версий на определенном этапе исследования на основе имеющейся на этом этапе информации; определение проблем, которые 
необходимо решить в соответствии с определенной версии; дифференциацию уголовных и специальных следственных мероприятий, которые следует провести для достижения желаемой цели; проверку версий по результатам специального и уголовного расследования; оценку результатов.

Сделан вывод, что вся организация расследования, ее планирование проводится динамично, а не фиксировано; план должен постоянно соотноситься с данными, полученными в ходе расследования уголовных дел, переходя от общего к частному. Рекомендовано для этой категории дел расследование преступлений проводить группой офицеров (всеми работниками уголовного розыска), что повысит качество и эффективность расследования.

Ключевые слова: преступление, план, версия, жертва, обстоятельство, организованная преступная группа, уголовное производство.

\section{DOI: 10.33766/2524-0323.93.305-315 УДК 355.404.6}

Тищук В. В., старший Викладач кафедри спеціальних дисицилін факультету правоохоронної діяльності Національної академії Державної прикордонної служби Украйни імені Богдана Хмельницького (м. Хмельницький, Украйна) e-mail:comua8@gmail.com

ORCID iD: https:/ /orcid.org/0000-0001-5811-5909

Сивовол Р. М., слухач факультету підготовки керівних кадрів Національної академії Державної прикордонної служби України імені Богдана Хмельницького (м. Хмельницький, Украӥна)

e-mail:nadpsu@dpsu.gov.ua

ORCID iD: https://orcid.org/0000-0003-2637-234X

\section{КРИМІНОЛОГІЧНИЙ ПРОФІЛЬ ОСОБИ, ЯКА ВЧИНИЛА РОЗГОЛОШЕННЯ ДЕРЖАВНОЇ ТАЄМНИЦ}

У статті досліджено елементи кримінологічного профілю особи, яка вчинила розголошення державної таємнищі. Дослідження проведено на основі аналізу статистичних даних Єдиного державного реєстру судових рішень України. У дослідженні були ощінені соціально-демографічні (стать, вік, освіта, національність) та кримінально-правові характеристики (мотивація злочинної поведінки, одноосібний чи груповий характер злочинних дій, тривалість злочинної діяльності, наявність чи відсутність судимості тощо). Узагальнення та інтерпретація результатів судових рішень надали можливість змоделювати типовий кримінологічний профіль особи злочинщя, що вчинив розголошення державної таємниці, та виділити окремі специфічні характеристики суб'єктів цього злочину.

Ключові слова: національна безпека, розголошення державної таємниці, Державна прикордонна служба України, кримінологічний профіль, особа злочинця, ознаки злочинщя, Єдиний державний реєстр судових рішень України.

Постановка проблеми. Державна таємниця виконує важливу роль у становленні державності та збереженні суверенності кожної країни. В умовах «інформа-

(C) Тищук В. В.,

Сивовол Р. М., 2021 